\title{
Post-Text and In-Text Corrective Feedback
}

\author{
John Bankier \\ Soka University, Japan
}

\begin{abstract}
A number of studies have shown that feedback on writing has a positive effect on improvements in drafts. Studies have focused on indirect and direct forms of feedback, as well as comparing different treatments of indirect feedback. In particular, studies have compared correction keys (in-text feedback) with highlighting or underlining errors. This paper describes an alternative system, post-text feedback, in which comments are made on language errors at the end of the text rather than through a correction key. The rationale for this system is described with reference to relevant research. To evaluate its potential effectiveness, two small groups of learners were given feedback based on two systems: in-text and post-text feedback. Written drafts from the participants were then compared to determine if post-text feedback led to an equal amount of correct revisions.
\end{abstract}

\section{Types of Feedback in L2 Writing}

Studies have researched feedback in terms of direct and indirect. In direct feedback, the teacher provides the form necessary to correct an error. In indirect feedback, the error is marked, but the correct form is not provided. Several types of indirect feedback are described below.

In-Text Coded Feedback. One example of indirect feedback is the usage of a correction key (see Appendix A) to mark errors within the text of the learner's writing. This type of feedback is usually referred to as coded feedback. A key consists of symbols or abbreviations corresponding to common errors. Table 1 shows an example of teacher feedback and the desired learner correction.

\section{Table 1}

\section{Correction Key Examples in Practice}

\begin{tabular}{ll}
\hline \multicolumn{1}{c}{$w f$} & Learner Revision \\
\hline I was very happiness. & I was very happy. \\
\hline I asked $\wedge$ brother. & I asked my brother. \\
\hline
\end{tabular}

Note. See Appendix A for the correction key. 
Research by Ferris (2006) demonstrated "a strong case for the superiority of indirect feedback over direct feedback for facilitating student writing improvement over time" with her particular population of students (p. 98). While there was no significant difference between direct and indirect feedback in the short term, longitudinally, students who had been given indirect coded feedback did improve more.

An important benefit of indirect coded feedback is that students may spend more time thinking about their mistakes, which may lead to more long-term improvement; this could be the reason for the long-term improvement shown by Ferris (2006). There is a possible drawback, however. If the teacher indicates every instance of a missing article, for instance, the student may not pay attention to the error. It is easy to simply add a missing definite or indefinite article without asking questions such as "Why should I use a here?" or "Why does this word take the?"

In-Text Uncoded Feedback. A second type of indirect feedback consists of highlighting errors in the text without a key, often called uncoded feedback. Learners are not given guidance on what particular type of error each error is. Research by Ferris and Roberts (2001) compared marking errors with codes, underlining errors alone, and no error feedback at all. The study compared drafts of learner writing which were commented on by teachers, and analyzed the drafts to determine if learners had corrected the errors. The findings showed that learners who had been given some form of error feedback performed better than those who had been given none. However, there was no significant difference between the two feedback treatments. Ferris and Roberts' (2001) findings correlated with earlier studies, such as that by Robb, Ross and Shortreed (1986, cited in Bitchener, Young, \& Cameron, 2005), whose study suggested that while feedback is beneficial, the type of feedback does not make a significant difference. In view of the teacher's workload, the conclusion that can be drawn from this is that it is better to use the simplest and quickest form of indirect feedback: uncoded highlighting with no correction key. However, all forms of feedback mentioned have potential drawbacks as well as benefits (see Table 2).

Post-Text Feedback. Post-text feedback is an alternative method of indirect feedback. As with uncoded feedback, the teacher highlights or underlines grammar and vocabulary errors in-text. The teacher then notes significant or repeated error forms and comments on them at the end of the text, maintaining the key advantages of in-text, coded feedback. The only in-text feedback consists of highlighting or underlining. Crucially, not every type of error needs to be mentioned. For instance, a minor mistake with subject-verb agreement, such as "He work in a bank," could simply be highlighted if it is not a recurring problem throughout the piece. In contrast, a problem with grammatical voice that potentially affects meaning, such as "The man was bite the snake," would be both highlighted and then commented upon post-text. There are several potential advantages to post-text feedback (see Table 2); one is that both learners and the teacher have an overview of common problems and do not have to look through the text to find repeated errors. 


\section{Table 2}

A Comparison of Types of Feedback

\begin{tabular}{|c|c|c|c|c|}
\hline \multirow[b]{2}{*}{ Direct } & & Description & Advantages & Disadvantages \\
\hline & & $\begin{array}{l}\text { Errors are } \\
\text { corrected by } \\
\text { writing the correct } \\
\text { word or sentence }\end{array}$ & Leads to correct revisions (S) & $\begin{array}{l}\text { Takes a great deal of time }(\mathrm{T}) \\
\text { Does not require cognitive } \\
\text { effort }(\mathrm{S}) \\
\text { Potentially less long-term } \\
\text { improvement }(\mathrm{S})\end{array}$ \\
\hline \multirow{3}{*}{ Indirect } & $\begin{array}{l}\text { In-text } \\
\text { (coded) }\end{array}$ & $\begin{array}{l}\text { Errors are marked } \\
\text { using a correction } \\
\text { key }\end{array}$ & $\begin{array}{l}\text { Leads to correct revisions }(\mathrm{S}) \\
\text { Requires cognitive effort }(\mathrm{S}) \\
\text { Potentially more long-term } \\
\text { improvement }(\mathrm{S})\end{array}$ & $\begin{array}{l}\text { Takes time }(\mathrm{T}) \\
\text { More difficult for learners to } \\
\text { acquire an overview of } \\
\text { common problems }(\mathrm{S}) \\
\text { More difficult to use for } \\
\text { review }(\mathrm{S} / \mathrm{T})\end{array}$ \\
\hline & $\begin{array}{l}\text { In-text } \\
\text { (uncoded) }\end{array}$ & $\begin{array}{l}\text { Errors are } \\
\text { highlighted or } \\
\text { underlined only }\end{array}$ & $\begin{array}{l}\text { Quick }(\mathrm{T}) \\
\text { Leads to correct revisions }(\mathrm{S}) \\
\text { Requires cognitive effort }(\mathrm{S}) \\
\text { Potentially more long-term } \\
\text { improvement }(\mathrm{S})\end{array}$ & $\begin{array}{l}\text { Potentially demotivating (S / } \\
\text { T) } \\
\text { More difficult for beginner } \\
\text { learners }(\mathrm{S}) \\
\text { Difficult to use for content } \\
\text { feedback }(\mathrm{T})\end{array}$ \\
\hline & Post-text & $\begin{array}{l}\text { Errors are } \\
\text { highlighted and a } \\
\text { summary is given } \\
\text { at end of the text }\end{array}$ & $\begin{array}{l}\text { Leads to correct revisions }(\mathrm{S}) \\
\text { Requires cognitive effort }(\mathrm{S}) \\
\text { Potentially more long-term } \\
\text { improvement }(\mathrm{S}) \\
\text { Easy to use for review }(\mathrm{S})\end{array}$ & \\
\hline
\end{tabular}

Note. $(\mathrm{T})$ refers to the perspective of teachers, $(\mathrm{S})$ to that of students.

\section{A Note on Content and Language Feedback}

The studies mentioned above focused on errors in language, including grammar, vocabulary usage (and spelling), as well as other linguistic features such as transition signals. Other studies have focused on content feedback. Content is the meaning or message of the text, rather than the language. Content comments may focus on the accuracy of statements or on support for propositions. As Ferris (2003) notes, assessing improvements in content is problematic. Studies have analyzed content scores after content feedback, but this is a subjective measure. Kepner (1991, cited in Ferris, 2003, p. 37) suggested that "message-related" feedback had a positive impact on students' thinking and writing skills, but again this is difficult to assess in an objective way. It was felt that content feedback was less relevant to the post- and in-text distinction; therefore, in this study, only comments on language were analyzed.

To evaluate the post- and in-text systems of feedback, action research was conducted on a small group of students. Focusing on errors in language (including in discourse), students' essay drafts were analyzed to determine if post-text feedback led to fewer correct revisions than in-text feedback.

\section{Action Research Question}

Does post-text feedback lead to fewer correct revisions than in-text feedback for language errors? 


\section{Methodology}

\section{Participants and Instructional Context}

The participants were four first-year university students in Japan. They were enrolled in an intensive English language program. The study took place during the fall semester, the second semester of the program. All entrants to the program had a minimum GPA of 3.7 on a fourpoint scale and a TOEFL ITP score ranging from 450 to 487 . Thus, in the view of the author, they were motivated to pay attention to the feedback given by the teacher.

Four students were selected at random for the study at the end of the course. It was felt that an in-depth analysis of the students' work would be sufficient; however, a larger sample would have been beneficial (see the discussion of limitations in the Conclusion). Each of the two pairs of students took part in different sections of the same course. Each class comprised 15 students, all of whom received the same essay assignments. Both classes were taught by the author and followed an identical syllabus and curriculum. The only difference was in the method of feedback used.

\section{Design}

The four participants completed three essay assignments, each with four drafts. The assignments were typically around 650 words. The topics were chosen by the students, based on a framework given by the teacher. For instance, students were assigned a comparison and contrast essay in which they compared two countries of their choice.

The drafting procedure followed the POWER-S System, summarized in Table 3 below. The POWER System has been used by a number of practitioners, including Anderson, Raphael, Englert, and Stevens (1992), and Kluge and Taylor (2007). It was further refined by Aloiau (2009), who added the final "Share" stage in which writing is shared with peers.

\section{Table 3}

\section{The POWER-S System}

\begin{tabular}{ll}
\hline Stages & Description \\
\hline Pre-write & Learners generate ideas through discussion or free-writing \\
Organize & The ideas are organized into a coherent plan \\
Write & The first draft \\
Evaluate & The draft is evaluated \\
Rewrite & A second draft is produced \\
Share & This draft is shared with others (peers or the teacher) \\
\cline { 2 - 2 } & The process then returns to edit, rewrite and share until a final draft is produced \\
\hline
\end{tabular}

Based on POWER-S, the drafting process consisted of four drafts for each assignment. The first draft was a rough draft. It was edited by the student alone, with some general guidance from the teacher for the class as a whole in the form of an editing checklist and "mini lectures" on common problems. Learners then wrote a second draft. This was edited by their peers, the other students in the class. Again, general guidance was provided. Students then wrote a third draft, which they submitted to the teacher. It was this draft that received the written feedback. Based on the comments, the students revised and produced a final draft (FD). This draft then received further feedback; in terms of language, this consisted of a checkmark against errors that had been corrected, and direction correction of those that had not.

From an individual learner's perspective, it can be argued that it is most beneficial for students to receive comments from the teacher on all drafts. However, comments were reserved until 
the third draft (D3) for three main reasons. Firstly, self-editing builds learner autonomy and encourages a cooperative relationship with the teacher (Cresswell, 2000; Ferris, 2002).

Secondly, peer-editing allows students to learn from each other, as well as fostering a more positive affective environment (Hafernik, 1983). Finally, it is impractical in terms of time for most teachers to comment on four drafts of each assignment, and thus for this study would not reflect actual teaching practice.

Participants in one class, referred to henceforth as Student $1 \mathrm{a}$ and Student $1 \mathrm{~b}$, were given intext coded feedback on their D3. A correction key was used (see Appendix A). Participants in the second class, referred to as Student $2 a$ and Student $2 b$, were given post-text feedback on D3. Errors were highlighted in the body of the text. Important comments were given at the end of the text.

Both groups also received direct feedback on errors judged untreatable. These were errors beyond the learners" current level of language development. For instance, the error "In both countries, people eat rice main dish" was corrected to "In both countries, people eat rice as their staple dish." The phrase "staple dish" was necessary for the essay, but it was felt that the student could not correct this alone. These corrections were disregarded in the study.

The four participants' essays were analyzed, focusing on errors in language. Errors from D3 were compared with the revisions in the FD. If the problem commented on had been revised correctly, the error was judged to be corrected. Occasionally, other developmental issues arose as a result of learners acting on teacher feedback: correcting one error led to another error emerging. For instance, in the phrase "Recently, biomass energy use is increase ..." is increase was marked as a verb error. The participant corrected the phrase to "Recently, biomass energy has increased to use." The verb error was corrected to the appropriate present perfect form. However, in the first phrase, use was employed correctly as a noun, while in the FD, use was incorrectly changed to the infinitive form. These developmental errors were disregarded in this study, as it was felt that these errors were unlikely to be connected to particular styles of feedback. In other words, the errors were caused by learners making the revisions, rather than the way that the teacher commented on them. Further research may be needed to determine whether or not this is the case.

\section{Results}

Across the two groups, 44 errors were commented on indirectly by either in-text or post-text feedback. A large number of errors, 110, were also commented on directly, the majority of which consisted of deleting or inserting particular words (see Appendix B for examples). Occasionally, the teacher corrected whole sentences. The students appropriately revised all direct corrections in the FD.

The in-text group corrected $74.1 \%$ of the errors commented on by the teacher in D3, a total of 20 out of 27 . Of the remaining seven errors, one was not corrected at all and six were incorrectly revised in the FD.

The post-text group was able to correct $82.4 \%$ of the errors in the FD. Fourteen errors out of 17 were corrected, and three were not corrected at all.

There were some differences between the two feedback styles. One noticeable difference was that post-text feedback led to revisions that were either correct or were not revised.

Contrastively, in-text feedback led to several incorrect revisions, but no errors were left 
unchanged. This may be an effect of the level of language skills of the learners: five of the incorrect revisions were made by Student $1 \mathrm{a}$ and two by Student $1 \mathrm{~b}$. Student $2 \mathrm{a}$ revised all but one error correctly, while Student $2 b$ left two errors uncorrected. Using a correction key may lead learners to try to correct errors, but highlighting text may be insufficient if the problem is unclear to the learner.

Certain types of errors appeared to lend themselves best to certain types of feedback. Examples from the learner texts are given in Appendix C.

\section{In-Text Group}

Articles. Correction of article errors from in-text correction was variable. Thirteen errors were commented on, of which three were not corrected. This suggests that, while students are aware that an article needs to be used, a correction key does not help them choose the correct one ( $a$, an, or the). It is possible that post-test feedback may be more effective. The teacher can give advice on, for example, article usage, such as "Use the when there is only one. Example: The Japanese government."

Word Forms. Students made errors using word forms, such as using "environmental" rather than "environment." Student 1a's writing contained three errors in word forms that were commented on using a correction key; two were successfully corrected (see Appendix C). It is possible that the sentence structure affected how easy these forms were to correct. In the example below, the word following on in "are based on" is clearly a noun. In contrast, the sentence "...both countries are good environmental to raise rice" the presence of nouns and verbs (raise, rice) may have made the sentence less clear. Post-text comments, however, could have given an example of how to use this structure: "Harajuku is a good place to go shopping $=X+$ be + article + adj. + noun + infinitive."

\section{Post-Text Group}

Transition Signals. "However," "In contrast," and "For example" are common transition signals. A number of errors were found in both Student $2 a$ and Student $2 b^{\prime}$ 's texts. These errors were highlighted, and the learners were able to add an appropriate transition in all seven instances.

Word Forms. Both Student $2 \mathrm{a}$ and Student $2 \mathrm{~b}$ made word form errors (three and two, respectively); these were commented on post-text. Student $2 \mathrm{a}$ was able to correct all errors. As shown in the example in Appendix C, giving the learner an example of a similar sentence can be enough. It is important to recall that the highlighted portions of the text were not numbered or linked to the post-text comments; this was to encourage students to spend more time evaluating their own errors.

\section{Conclusions and Future Research}

In this study, learners were able to make corrections to their writing based on both types of feedback. Although post-text comments led to a slightly higher percentage of correct revisions, the amount and types of errors compared were different, so it is impossible to draw any conclusions from the results.

However, the two types of feedback are not necessarily equally well suited to all errors. A combination of feedback types is likely to be the most beneficial to learners. Post-text comments may be effective for easily generalizable errors with such as rules as "Use the when there is only one" or "be + influenced + by + something." When a correction key is used, 
some types of errors may lead learners to randomly select an article or verb form, for example. In contrast, post-text feedback may assist learners in noticing a general rule.

There were a number of important limitations regarding this study. Firstly, due to the small sample size, it was difficult to compare how learners actually corrected errors. With a larger sample size, it would be possible to compare particular errors, such as word forms, to determine which feedback form led to more correct revisions. Secondly, the small sample size also meant that the individual learner was a more important factor than the feedback type. Learners may have been able to correct their writing regardless of the style of feedback given. Finally, it was not clear if learners were paying attention to the post-text comments or not; it was not possible to determine if errors were corrected as a result of the type of feedback or simply because some form of feedback was given. Future research is thus required to determine which of the forms of the feedback is more effective in a wider sense.

\section{Author Note}

John Bankier, World Language Center, Soka University, Tokyo, Japan.

Correspondence should be addressed to John Bankier, World Language Center, Soka University, 1-236 Tangi-cho, Hachioji City, Tokyo, 192-8577 Japan. Email:

johnbankier@yahoo.co.uk 


\section{References}

Aloiau, E. K. W. (2009, July 14). TESOL 8616: Teaching second and foreign language skills. Materials presented in a classroom lecture at Temple University, Japan Campus, Tokyo.

Anderson, L. M., Raphael, T. E., Englert, C. S., \& Stevens, D. D. (1992). Teaching writing with a new instructional model: Variations in teachers' beliefs, instructional practice, and their students' performance. National Center for Research on Teacher Learning. Retrieved from http://ncrtl.msu.edu/http/rreports/html/pdf/rr917.pdf

Bitchener, J., Young, S., \& Cameron, D. (2005). The effect of different types of corrective feedback on ESL student writing. Journal of Second Language Writing, 14(3), 191-205. http://dx.doi.org/10.1016/j.jslw.2005.08.001

Cresswell, A. (2000). Self-monitoring in student writing: developing learner responsibility. ELT Journal, 54(3), 235-244. http://dx.doi.org/10.1093/elt/54.3.235

Ferris, D. (2002). Treatment of error in second language writing. Ann Arbor, MI: University of Michigan Press.

Ferris, D. (2003). Response to student writing: Implications for second language students. Mahwah, NJ: Lawrence Erlbaum

Ferris, D. (2006). Does error feedback help student writers? New evidence on the short- and long-term effects of written error correction. In K. Hyland \& F. Hyland (Eds.), Feedback in second language writing: Contexts and issues. Cambridge, England: Cambridge University Press.

Ferris, D., \& Roberts, B. (2001). Error feedback in L2 writing classes: How explicit does it need to be? Journal of Second Language Writing, 10(3), 161-184. http://dx.doi.org/10.1016/S1060-3743(01)00039-X

Hafernik, J. J. (1983). The how and why of peer editing in the ESL writing class. CATESOL Occasional Papers, 10, 48-58.

Kluge, D. E., \& Taylor, M. A. (2007). Basic steps to writing research papers. Tokyo, Japan: Cengage Learning.

Oshima, A., \& Hogue, A. (2006). Introduction to academic writing ( $3^{\text {rd }}$ ed.). New York, NY: Pearson Longman. 
Appendix A

Example of a Correction Key

\begin{tabular}{|c|c|}
\hline$v t$ & $\begin{array}{l}\text { Verb tense } \\
x \quad \text { I have been to France last year. } \\
\checkmark \quad \text { I went to France last year. }\end{array}$ \\
\hline$W W$ & $\begin{array}{l}\text { Wrong word } \\
\mathrm{x} \quad \text { The company was born. } \\
\checkmark \quad \text { The company was established. }\end{array}$ \\
\hline$w f$ & $\begin{array}{ll} & \text { Wrong form } \\
x & \text { He introduction the plan. } \\
\checkmark & \text { He introduced the plan. }\end{array}$ \\
\hline$p$ & $\begin{array}{l}\text { Punctuation } \\
x \quad \text { I bought some ice cream but my dog ate it. } \\
\checkmark \quad \text { I bought some ice cream, but my dog ate it. }\end{array}$ \\
\hline$s p$ & $\begin{array}{l}\text { Spelling } \\
x \quad \text { She was very speicial. } \\
\checkmark \quad \text { She was very special. }\end{array}$ \\
\hline Japan and USA is both... & $\begin{array}{l}\text { (Highlighted) Easy mistake } \\
\text { Check your essay better! } \\
\checkmark \quad \text { Japan and the USA are both... }\end{array}$ \\
\hline $\begin{array}{c}\text { ? ? ? } \\
\text { The plan was aspectation of many instance. }\end{array}$ & $\begin{array}{l}\text { I do not understand all of this. } \\
\text { Write it again using different words. }\end{array}$ \\
\hline I agreed. So we went there. & $\begin{array}{l}\text { Link these sentences } \\
\checkmark \quad \text { I agreed, so we went there. }\end{array}$ \\
\hline I asked $\wedge_{\wedge}$ brother. & $\begin{array}{l}\text { Missing word } \\
\checkmark \quad \text { I asked my brother. }\end{array}$ \\
\hline Also, I enjoy fishing. & $\begin{array}{l}\text { Move this here } \\
\checkmark \quad I \text { also enjoy fishing. }\end{array}$ \\
\hline $\begin{array}{l}\text { fave } \\
\text { I often visited Hawail. }\end{array}$ & $\begin{array}{l}\text { Add this here } \\
\checkmark \quad \text { I have often visited Hawaii. }\end{array}$ \\
\hline
\end{tabular}

Adapted from Oshima \& Hogue (2006). Introduction to academic writing (3 ${ }^{\text {rd }}$ ed.). New York: Pearson Longman. 
Appendix B

Examples of Direct Feedback

\section{Direct Correction}

\begin{tabular}{lll}
\hline \multicolumn{1}{c}{ Teacher comment } & \multicolumn{1}{c}{ Reason } & \multicolumn{1}{c}{ Learner revision } \\
\hline $\begin{array}{l}\text { think that-people should sometimes do things } \\
\text { that they do not enjoy. }\end{array}$ & $\begin{array}{l}\text { Unnecessary use of } \\
\text { "I think" }\end{array}$ & $\begin{array}{l}\text { People should sometimes do } \\
\text { things that they do not enjoy. }\end{array}$ \\
$\begin{array}{l}\text { Secondly, most societies function with people's } \\
\text { effort. }\end{array}$ & "With" is unclear & $\begin{array}{l}\text { Secondly, most societies } \\
\text { function as a result of people's } \\
\text { effort. }\end{array}$ \\
\hline
\end{tabular}




\section{Appendix C}

Examples of Successful and Unsuccessful Revisions

\begin{tabular}{|c|c|c|c|}
\hline \multicolumn{4}{|c|}{ In-Text Feedback } \\
\hline $\begin{array}{l}\text { Error type / } \\
\text { Student }\end{array}$ & Teacher comment & Learner revision & $\begin{array}{l}\text { Successful } \\
\mathrm{Y} / \mathrm{N}\end{array}$ \\
\hline $\begin{array}{l}\text { Article / } \\
\text { Student 1b }\end{array}$ & $\begin{array}{l}\text { Today there are many companies ... in } \wedge \\
\text { financial industry }\end{array}$ & $\begin{array}{l}\text { Today there are many } \\
\text { companies ... in } \underline{a} \\
\text { financial industry }\end{array}$ & $\mathrm{N}$ \\
\hline $\begin{array}{l}\text { Word form / } \\
\text { Student 1a }\end{array}$ & $\begin{array}{l}\qquad . \quad w f \\
\text { raise rice }\end{array}$ & No revision & $\mathrm{N}$ \\
\hline $\begin{array}{l}\text { Word form / } \\
\text { Student 1a }\end{array}$ & $\begin{array}{l}\text { However, both political systems are based on } \\
\quad w f \\
\text { democratic. }\end{array}$ & $\begin{array}{l}\text { However, both political } \\
\text { systems are based on } \\
\text { democracy. }\end{array}$ & $\mathrm{Y}$ \\
\hline $\begin{array}{l}\text { Missing } \\
\text { word / } \\
\text { Student } 1 \mathrm{~b}\end{array}$ & $\begin{array}{l}\text { For example, } \wedge \text { Mitsubushi UFJ bank's first } \\
\text { grade workers who graduated from university } \\
\text { are two millon yen. }\end{array}$ & $\begin{array}{l}\text { For example, wages of } \\
\text { Mitsubishi UFJ bank's } \\
\text { first grade workers who } \\
\text { graduated from university } \\
\text { are two million yen. }\end{array}$ & $Y^{*}$ \\
\hline \multicolumn{4}{|c|}{ Post-Text Feedback } \\
\hline $\begin{array}{l}\text { Error type / } \\
\text { Student }\end{array}$ & Teacher comment & Learner revision & $\begin{array}{l}\text { Successful } \\
\mathrm{Y} / \mathrm{N}\end{array}$ \\
\hline $\begin{array}{l}\text { Transition } \\
\text { signal / } \\
\text { Student 2a }\end{array}$ & $\begin{array}{l}\text { It means that the person who has talent can skip } \\
\text { the grade regardless of age. Young people may } \\
\text { study with elder friends. } \\
\text { Post-text comments: } \\
\text { Use more transitions. } \\
\text { Result = Therefore, / As a result, } \\
\text { More = Furthermore, / In addition, }\end{array}$ & $\begin{array}{l}\text {... Therefore, young } \\
\text { people may study with } \\
\text { elder friends. }\end{array}$ & $\mathrm{Y}$ \\
\hline $\begin{array}{l}\text { Transition } \\
\text { signal / } \\
\text { Student 2a }\end{array}$ & $\begin{array}{l}\text { On the other hand, in Japan, we cannot do that. } \\
\text { Alse the two countries are different in terms of } \\
\text { treating children. } \\
\text { Post-text comments: } \\
\text { Use firstly, secondly, finally to separate points }\end{array}$ & $\begin{array}{l}\text {... Secondly, the two } \\
\text { countries are different in } \\
\text { terms of treating children. }\end{array}$ & $\mathrm{Y}$ \\
\hline $\begin{array}{l}\text { Word form / } \\
\text { Student } 2 \mathrm{a}\end{array}$ & $\begin{array}{l}\text { Japan was strong effect by America } \\
\text { Post-text comments: } \\
\text { Use an adverb with verbs } \\
\text { Be + adv. + influenced + by + something } \\
\text { She was greatly influenced by her mother. }\end{array}$ & $\begin{array}{l}\text { Japan was affected by } \\
\text { America strongly }\end{array}$ & $\mathrm{Y}^{* *}$ \\
\hline
\end{tabular}

* Note. The article is missing, but the main issue has been addressed.

**Note. This example was different from that given by the teacher, yet the word form is correct. 